Article

\title{
The Impact of Labour Rights Commitments in EU Trade Agreements: The Case of Peru
}

\author{
Jan Orbie *, Lore Van den Putte and Deborah Martens
}

Centre for EU Studies, Department of Political Science, Ghent University, 9000 Ghent, Belgium; E-Mails: jan.orbie@ugent.be (J.O.), lore.vandenputte@ugent.be (L.V.d.P.), deborah.martens@ugent.be (D.M.)

* Corresponding author

Submitted: 3 July 2017 | Accepted: 8 September 2017 | Published: 14 December 2017

\begin{abstract}
While the inclusion of labour rights in European Union (EU) trade agreements has become an 'unobjectionable norm', analyses of their impact have been largely absent from the literature. This article aims to partly fill this gap in existing research by examining the impact of labour rights commitments in the EU-Peru-Colombia agreement, with particular reference to the agricultural sector in Peru. Following a brief background overview of labour rights in agriculture in Peru, we draw up the analytical framework for assessing the impact of these commitments. We discern three distinctive legal commitments and find that they are flexible and conservative, also compared to provisions in other EU trade agreements. Subsequently, we assess the impact of these commitments by analysing to what extent they are being upheld in practice. Empirical evidence from several sources, including field research, shows that the Peruvian government has failed to implement the labour rights commitments in several respects. In the conclusions, we point to the cautious role of the EU, which has scope to monitor Peru's labour rights compliance more proactively.
\end{abstract}

\section{Keywords}

agriculture; European Union; labour; Peru; sustainable development; trade

\section{Issue}

This article is part of the issue "Labour Standards in a Global Environment", edited by Gerda Van Roozendaal (University of Groningen, The Netherlands) and Jan Orbie (Ghent University, Belgium).

(C) 2017 by the authors; licensee Cogitatio (Lisbon, Portugal). This article is licensed under a Creative Commons Attribution 4.0 International License (CC BY).

\section{Introduction}

Recent European Union (EU) trade agreements contain a separate Title on 'Trade and Sustainable Development' where the Parties pledge to respect a number of social and environmental principles. This resonates with a growing concern that trade agreements should not only promote economic interests but should also take broader values into account. While the inclusion of labour rights in EU trade agreements has become an 'unobjectionable norm' (Van den Putte \& Orbie, 2015), analyses of their impact have been largely absent from the literature. This article aims to partly fill this gap by examining the impact of labour rights commitments in the EUPeru-Colombia agreement, with particular reference to the agricultural sector in Peru.
Our contribution to existing research is twofold. First, we provide an analytical framework specifying what exactly the labour rights commitments in the sustainable development title of the EU-Peru-Colombia agreement imply. While existing studies have analysed these commitments, this has often been done to illustrate the absence of enforceability through sanctions. Instead, we provide a more detailed account of the labour rights commitments. This also involves a comparison with other recent agreements concluded by the EU. While existing research has neglected the differences between the 'new generation' trade agreements, we show that the provisions on civil society monitoring in the EU-PeruColombia agreement are less far-reaching than in other agreements, and that this has potentially important implications in practice. 
Second, we apply this analytical framework to assess the impact of these legal commitments. Whereas academic research on the EU's inclusion of labour norms in trade has expanded in recent years (e.g. Marx, Wouters, Rayp, \& Beke, 2015), most studies focus on the design of the EU's trade-labour linkage, often comparing it to the trade-labour linkage of the US (Campling, Harrison, Richardson, \& Smith, 2016; International Institute for Labour Studies, 2013, 2016). Here, a distinction is often made between a 'soft' EU approach and a 'hard' US approach (Brown, 2015; Ebert \& Posthuma, 2011; Horn, Mavroidis, \& Sapir 2010). While the limited number of impact analyses focus on large- $\mathrm{N}$ quantitative data (Gansemans, Martens, D'Haese, \& Orbie, 2017, in this issue; Postnikov \& Bastiaens, 2014) or third country level analysis (Oehri, 2015a, 2015b; Van Roozendaal, 2017; Vogt, 2017), we aim to delve deeper into the case of labour rights in the agricultural sector in Peru, considering specific sub-cases such as labour inspection, health and safety at work regulations, and export regimes. Moreover, we analyse the provisions on civil society involvement, as these foresee trade union participation and are seen by the EU as a key mechanism to promote labour rights.

While this study has an explicit focus on the agricultural export sector, we also consider the broader context and evolution of labour rights in Peru. Our findings on the labour rights commitments in the trade agreement are also relevant to Colombia (and to some extent to countries subject to other EU trade agreements), and our analysis of its impact, for instance through civil society involvement, is also relevant to other sectors in Peru (and to some extent to Colombia and other trade agreements). Since Peru has struggled to implement (core) labour rights and agriculture is one of the most precarious sectors, this may seem a difficult case where significant EU impact cannot be expected. On the other hand, there is in this case much scope for external actors to achieve progress, and large- $\mathrm{N}$ studies (Postnikov \& Bastiaens, 2014) suggest that free trade agreements that include labour provisions do improve labour rights. Such studies should be complemented with detailed case studies of specific (sectors within) countries to gain more indepth empirical knowledge of how exactly the labour rights commitments within the trade agreement are being implemented on the ground. While not all the findings may be generalizable, they may be relevant for further comparative analysis using the same analytical framework as in this study. The focus on Peru is also appropriate because the EU-Peru-Colombia agreement is one of the earliest of the new generation of EU trade agreements (signed in 2010, in force since 2013).

Methodologically, this article is based on the trade agreement and other primary sources, secondary literature, participatory observation in an EU Domestic Advisory Group (DAG) meeting of the EU-Peru-Colombia agreement where a previous version of the article was presented (7 April 2016) and a transnational meeting in Brussels (8 December 2016), and most importantly a field visit to Lima and Trujillo (February-March 2016) which involved about 40 semi-structured interviews with officials from the EU, Peru and EU member states, employers and business associations, exporters, academics, NGO representatives, activists, trade unionists and workers. Interviews were also held with officials and stakeholders in Brussels. ${ }^{1}$

The structure of the article is as follows. First, we explain our focus on the agricultural sector in Peru and provide the necessary background on this case. Second, we draw up the analytical framework for assessing the impact of the trade agreement, focusing on three distinctive labour rights-related commitments. In this stage, we find that the legal commitments are flexible and conservative. Third, we examine to what extent these commitments have been upheld in recent years, thereby assessing the impact of the agreement in Peru. Empirical evidence suggests that the labour rights commitments have had no discernible impact. Fourth, the conclusions point to the cautious role of the EU in engaging even with the 'soft' approach to promote labour rights through trade.

\section{Background: Peru, Labour Rights and Agriculture}

During the negotiation, ratification and implementation phases of the EU-Peru-Colombia agreement, most of the debate in the EU, for instance in the European Parliament, concerning labour and human rights has focused on Colombia (see, for example, the debate on the trade agreement in the European Parliament in Strasbourg on 22 May 2012). Despite being 'in the shadow' of Colombia, significant problems with labour rights exist in Peru.

The labour rights situation in Peru displays three characteristics. First, the level of informality is still very high (more than 68\% in 2012 according to FORLAC, 2014). Second, the labour law is highly fragmented. While Peru has an elaborate labour code, legislation is dispersed, resulting in almost 40 different labour regulations applying to different kinds of work (Organisation for Economic Cooperation and Development [OECD], 2015, pp. 87-89; Verbeek, 2014). Third, there are serious shortcomings with the core labour standards (CLS). Peru has ratified the eight fundamental conventions of the International Labour Organization (ILO) on trade union rights, child labour, forced labour and non-discrimination. However, concerns have been raised regarding their implementation, as will be shown below.

Labour rights concerns are most prominent in the mining and agricultural sector. While the situation in the extractive industry has been amply documented (see, for example, Verité, n.d.), less research has been done on the agricultural sector (for exceptions, see, for example, Ferm, 2008; Schuster \& Maertens, 2017), even though

\footnotetext{
${ }^{1}$ We do not reveal the names of interviewees, as several have asked us not to disclose their identity or institutions. We can provide names upon request, if the interviewees have given permission for us to do so. When necessary, quotations from Spanish have been translated in English.
} 
this sector is notorious worldwide for poor working conditions and income distribution (Cheong, Jansen, \& Peters, 2013 , p. 9). Another reason for focusing on agriculture is the importance of this sector in Peru's economy. The agricultural export sector, especially in non-traditional goods such as asparagus, avocado and grapes, has been an important driver of Peru's growing economy in the last decade in terms of the number of companies, export volume and jobs (CEPAL, OIT, \& FAO, 2012a, p. 199; International Commission of Jurists, 2014, pp. 12-13; Velazco \& Pinilla, 2017). In 2015, the agricultural sector as a whole represented $7.8 \%$ of Peru's Gross Domestic Product and employed nearly $25 \%$ of the economically active population in 2013 (World Bank, 2017a, 2017b). Finally, even compared to the US market, Peru has exported a large amount of its agricultural produce to the EU.

The Agricultural Sector Promotion Law (Law No. 27360) seems to be paramount in this story. This law was enacted in 2000 to promote private investment and increase competitiveness and productivity in the sector by reducing labour costs and granting tax exemptions to companies (CEPAL et al., 2012a, p. 228). The first article of the law, which describes its general objective, states that its primary purpose is to support investment and development in the agricultural sector.

\section{Analytical Framework: Flexible and Conservative Commitments}

In order to be able to assess the impact of the trade agreement's labour rights provisions, we need to specify what exactly the treaty partners have committed to. Surprisingly, very little research has been conducted so far to analyse precisely what the Parties have committed to within the different EU trade agreements. Despite several ambiguities in the legal text of the agreement, we can discern three basic commitments: (1) upholding ILO CLS, (2) not lowering domestic labour law, and (3) promoting civil society involvement. Below, we will specify each of these commitments with reference to the legal text; taken together, this constitutes our analytical framework for assessing impact in the next section. The framework is analytical (but not theoretical or conceptual) as it summarises various specific textual commitments in three broad categories, which then serves to structure the empirical analysis. Despite differences in precise legal provisions, the same framework can therefore also be used to analyse labour rights commitments in other new generation EU trade agreements. The first and second commitments could lead to what Van Roozendaal and Orbie (2017) call institution building and legal improvement impact, whereas the third corresponds to empowerment impact.

First, the Parties commit to complying with the four 'core' and universal labour rights or principles of the 1998 ILO Declaration on Fundamental Principles and Rights at Work. Each of these four corresponds to two ILO conventions: freedom of association and the effec- tive recognition of the right to collective bargaining (Conventions No. 87 and 98), the elimination of forced or compulsory labour (No. 29 and No. 105), the abolition of child labour (No. 138 and No. 182) and the elimination of discrimination in respect of employment and occupation (No. 100 and No. 111). In the chapter on trade and sustainable development of the EU-Peru-Colombia trade agreement, each Party commits itself to the promotion and effective implementation in its laws and practice and in its whole territory' (Art. 269.3) of these ILO $\mathrm{CLS}$. The agreement does not explicitly stipulate that ratification of the eight ILO conventions is necessary. Prior to securing its market access through this trade agreement, Peru was a beneficiary of the EU's unilateral Generalised System of Preferences Plus (GSP+). This system includes a social conditionality regime that requires the 'ratification and effective implementation' of all ILO core conventions (Velluti, 2015). GSP preferences may be partly or completely withdrawn when compliance with these conventions is lacking. Therefore, the legal enforcement provisions in the trade agreement are weaker compared to those in the previous trade regime under the GSP+. That said, in practice, also under the GSP+, the EU has rarely resorted to withdrawal of preferences. Peru had already ratified the relevant ILO conventions in 2002 and there are no indications that the GSP+ has improved the implementation of labour rights in the country (Orbie \& Tortell, 2009, pp. 677-678). However, the point remains that it has become more difficult to sanction non-compliance with the ILO conventions, which may be relevant provided that there is sufficient political will within the EU to take such steps.

Second, the Parties make a strong commitment not to lower de jure or de facto the level of protection provided in the labour law, at least not in a way that would foster trade or investment. The obligation to 'upholding levels of protection' is written down very clearly in Art. 277. It states that 'no Party shall waive or otherwise derogate from its environmental and labour laws in a manner that reduces the protection afforded in those laws, to encourage trade or investment' (Art. 277.1), and that 'A Party shall not fail to effectively enforce its environmental and labour laws through a sustained or recurring course of action or inaction, in a manner affecting trade or investment between the Parties' (Art. 277.2). It is clear that this commitment concerns not only the de jure level of protection, but also de facto enforcement or any other forms of derogation to the level of protection that the law seeks to establish.

While this broadens the scope of this commitment, there is also a limitation in that there needs to be an impact of the non-lowering on trade and investment. The difficulty is not only that one has to prove that there has been a weakening of labour standards, but also that this has been done in such a way that trade and/or investment has been encouraged. Both the intentionality behind such measures and their economic impact on trade and investment are difficult to demonstrate. 
In addition, the Parties' right to regulate is stressed. They have 'the right...to a reasonable exercise of discretion with regard to decisions on resource allocation relating to investigation, control and enforcement of domestic...labour regulations and standards, while not undermining the fulfilment of the obligations undertaken under this Title' (Art. 277.3) and 'Nothing in this Title shall be construed to empower the authorities of a Party to undertake labour...law enforcement activities in the territory of another Party' (Art. 277.4). These provisions aim to establish limitations against international interference in the domestic regulation and application of labour rights.

Third, civil society meetings should take place in order to discuss and monitor these commitments to sustainable development (cf. empowerment impact). These meetings should be organised at two levels: domestically (within each Party) and transnationally (involving civil society from each Party). The domestic mechanisms of each Party (see Art. 281) should 'have a balanced representation'. Their task seems to extend beyond merely discussing the implementation of the chapter on trade and sustainable development: they 'may submit opinions and recommendations on the implementation of this Title, including on their own initiatives'. Such a domestic mechanism is often called a DAG. The transnational mechanism is organised in the context of the annual meeting of the Parties' Sub-committee on Trade and Sustainable Development, which is the intergovernmental body that oversees the implementation of this chapter. The same stakeholders as in the domestic mechanism should be given the opportunity to participate in these sessions. These are open meetings to which the public at large can also attend. The purpose is 'to carry out a dialogue' between civil society and governments on the implementation of the chapter on trade and sustainable development.

Again, as with the two previous commitments, there is a significant degree of flexibility for governments. A comparative analysis (using the database of Martens, Van den Putte, Oehri, \& Orbie, 2018) shows that these provisions are more constrained than in most other agreements (for a detailed analysis see Orbie \& Van den Putte, 2016). Among other things, the governments are not obliged to establish a new domestic mechanism to monitor this chapter on trade and sustainable development (Art. 281), the provisions for the domestic mechanism do not specify that members need to be 'independent' (Art. 281) and overall the agreement provides a great deal of leeway for governments to organise the meetings as they see fit (Art. 281). Many of the other recent trade agreements are more explicit on the need to establish a new mechanism (such as the EU-Korea agreement) or stress the need for independent membership.

In conclusion, the labour rights commitments are conservative and flexible. By 'conservative', we mean that they mostly aim to maintain the status quo (e.g. on domestic labour law and civil society mechanisms). No specific and additional labour reforms are required, nor is it necessary to establish a new civil society mechanism. By 'flexible', we mean that there is much leeway for the governments when it comes to labour protection at the domestic level and the functioning of the civil society mechanisms. Specifically, on upholding CLS and nonlowering domestic labour law, there is a significant degree of flexibility for governments, provided that (1) domestic labour protection is consistent with the ILO CLS, and (2) a reduced de jure or de facto level of protection does not serve to foster trade or investment. On promoting civil society dialogue, there is a significant degree of flexibility for governments, provided that (1) a domestic committee or group should exist, (2) it should be consulted by its government, and (3) the same stakeholders should be given the opportunity to participate in the transnational meeting.

\section{Assessing Impact}

In order to assess the impact of the labour rights commitments in the trade agreement, this section will systematically apply this analytical framework to the de facto situation of labour rights in Peru (with specific reference to the agricultural sector).

\subsection{Upholding ILO CLS}

Even though Peru has ratified the eight ILO core conventions, serious shortcomings can be noticed when it comes to the 'implementation in practice', as required in Art. 269.3. Reports and indicators from international institutions show that practices of child labour, forced labour, discrimination and violations of trade union rights continue to exist in Peru, and this is also the case in the agricultural sector. We make a distinction between 'process or enabling rights' such as trade union rights and 'outcome rights' such as the eradication of child labour as the former should enable the latter.

When it comes to child labour and forced labour, $33.5 \%$ of children aged five to 14 are engaged in child labour (UNICEF, n.d.; United Nations Development Programme, 2015). Most of them work in the agricultural sector or on the street. An estimated $0.218 \%$ of the population in Peru is in modern slavery (Walk Free Foundation, 2014). Interestingly, these shortcomings have already been reported by the European Commission. In its assessment report on the GSP+ scheme, the Commission analyses Peru's compliance with the eight conventions, partly relying on the findings of the ILO expert bodies (European Commission, 2016). It concludes that 'Peru has been taking several steps and has made some progress in implementing the ILO core labour standards', in particular regarding forced labour and child labour. However, it also finds that 'Peru faces problems in practically implementing and enforcing the fundamental conventions' and that 'stronger efforts are required' (European Commission, 2016, p. 260). Furthermore, Mujica argues that 
although there have been improvements in the national policies on child labour and forced labour, there continue to be problems in practice (2015, pp. 8-10).

When it comes to trade union rights, there is no clear evidence of any progress: quite the contrary. Trade union rights, as covered under ILO Conventions 87 and 98 on freedom of association and collective bargaining, are fundamental as they can create an enabling environment to protect other labour rights. Through the empowerment of workers, improvements in 'outcome rights' such as child labour can be expected (Barrientos \& Smith, 2007; Lieberwitz, 2006).

Peru was given a rating of four by the International Trade Union Confederation (ITUC) in the 2017 Global Rights Index; this rating is given to countries where systematic violations are reported (ITUC, 2017). In such countries, the government and/or companies continuously threaten workers' fundamental rights by making serious efforts to crush their collective voice. Relying on ILO reports, the European Commission also produced a critical evaluation of trade union rights in Peru.

Our interviews with workers and trade union representatives in Lima and Trujillo confirmed these obstacles to strike, to join a trade union, to bargain collectively, and to take legal action against trade union discrimination, also in the agricultural sector. For example, several interviewees mentioned that some workers did not receive a new contract because they were affiliated to a trade union, and that some were forced to de-unionise in order to see their contract renewed. They also mentioned practices whereby union representatives are framed for allegedly engaging in fraudulent practices in order to damage their credibility. Other violations of trade union rights include the alleged practice of drawing up 'black lists' of trade unionists, which makes it almost impossible for dismissed workers to find another job. These interviewees confirm practices that have also been documented in other reports (Fonds voor Ontwikkelingssamenwerking, 2015; International Commission of Jurists, 2014). For example, the general survey by the ITUC mentions several anti-union practices in agricultural export companies in 2014, with violent repression and detainment of workers at CAMPOSOL and the sacking of a newly elected trade union leader at TALSA ${ }^{2}$ (ITUC, n.d.).

Several explanations for these alleged violations can be given. Interviewees often point to the widespread use of temporary contracts. Specifically for the agricultural sector, there is the special law for the promotion of agricultural export products, Law No. 27360, under which workers enjoy only half of the workers' benefits provided under the general labour law (see below). According to several sources, including a prominent labour lawyer, this law is used beyond its original rationale. For example, temporary contracts are allowed to accommodate the specificities of seasonal labour in agriculture. However, large agricultural export companies cultivate several products all year round and employ the same labourers for these different products (see also Mujica, 2015). By hiring workers permanently on a temporary contract, it is far more difficult for them to organise themselves. More fundamentally, there is a strong anti-union climate in Peru, going back to historical episodes of political violence and economic collapse in the 1980s, which have been linked to trade union activities, and to the subsequent repressive reactions during President Fujimori's tenure (1990-2000). According to Mujica (2015, p. 10), the government (referring to the Humala government, 2011-2016) lacks the capacity and willingness to address this issue. He emphasises that this is not a problem of individual cases of violations of trade union rights, but that there has been a systematic policy behind the violations by the Peruvian governments. According to a European NGO representative with long expertise in labour rights in Peru, the situation for trade unions has actually worsened in recent years. The labour movement also suffers from internal divisions, as we witnessed in the agricultural sector in Trujillo and also in the representation of the unions in Lima.

It is not surprising, therefore, that the level of unionisation is extremely low in Peru. Peruvian unions never regained the status they enjoyed during the pre-Fujimori era (Gil Piedra \& Grompone Velásquez, 2014; Sulmont Samain, 2006). Trade union density was $4.2 \%$ in 2012 (ILO, n.d.). The figures are even lower in agriculture. In 2010, of 98,467 unionised people in the private sector, only 2,651 were agricultural workers. So while unionisation is already very low at the national level, it is even lower in the agricultural sector, which represents only $2.69 \%$ of all unionised people in Peru (RedGe, 2012, p. 24). In 2010 , about $1.4-1.7 \%$ of workers in the agricultural sector were unionised. In the Ica region, there used to be twelve trade unions, whereas now there are only two organisations that could be regarded as trade unions.

In the agricultural export sector, it should be noted that CAMPOSOL negotiated a collective labour agreement in December 2015. This agreement deals inter alia with economic benefits, labour conditions, health, CSR and union issues. However, trade union representatives at CAMPOSOL state that in practice, the social situation at CAMPOSOL is no better than at other agricultural export companies.

Whether these shortcomings represent a lack of 'implementation in practice' as required in the agreement remains difficult to determine, as the EU and its trading partners have not established clear benchmarks to evaluate gradations of implementation. In the context of the $\mathrm{GSP}(+)$, it has been noticed that the EU only resorts to sanctions when the ILO has established a Commission of Inquiry, which constitutes the highest level of condemnation (Orbie \& Tortell, 2009, p. 676); this does not mean that the threshold for identifying violations of the core labour rights should be set so high (Vogt, 2015). While the above-mentioned violations seem serious and sys-

\footnotetext{
${ }^{2}$ CAMPOSOL and TALSA are major agricultural exporters in the La Libertad region.
} 
tematic, the EU could engage in a reflection with its trading partners, civil society and the ILO on when exactly the core labour rights commitments are properly (even if never completely) implemented.

\subsection{Non-Lowering Domestic Labour Law}

Our research indicates three sub-cases where the labour protection has been lowered since the entry into force of the trade agreement with the EU: (1) de facto weakening of labour inspection; (2) de facto continuation of special (labour) regimes; (3) de jure lowering of health and safety at work. However, it remains difficult to ascertain whether this has an (intended) impact on trade or investment. Interestingly, in July 2015 a public submission was filed with the US Department of Labor by international NGOs and Peruvian workers' organisations, among others, under the US-Peru trade agreement (International Labor Rights Forum, 2015). The main allegation concerned the failure of the Peruvian government to effectively enforce its labour laws in the textile and agricultural sectors. While some consultation has taken place, the issue is still pending. No official public submission system exists under the EU agreement.

\subsubsection{De Facto Weakening of Labour Inspection}

While Peru has one of the most regulated labour markets in the world, it is among the countries with the lowest level of compliance with labour regulation (OECD, 2015 , p. 87). Although a new inspection agency, named SUNAFIL (Superintendencia Nacional de Fiscalización Laboral), was created in 2012, there is a widespread consensus among interviewees that this agency has not functioned. Since it started functioning on 1 April 2014, at least four structural problems have been identified.

First, as emphasised by an ILO official, SUNAFIL's resources are 'ridiculously low'. A labour lawyer stressed that the amount of underfunding is 'amazing'. There are currently only about $\mathbf{5 0 0}$ labour inspectors in Peru. SUNAFIL has 394 inspectors nationwide, of which 227 are spread over nine of the twenty-five regions (US Department of State, 2015, p. 33). The US Department of Labor recently requested Peru to establish SUNAFIL offices in all regions as soon as possible (US Department of Labor, 2016 , p. 19). In some regions there is only one labour inspector, and in the region of La Libertad there are only nine inspectors although this is a major agricultural export region where more than 80,000 companies are active (Mujica, 2015, p. 14).

Second, SUNAFIL does not function autonomously from the Peruvian government and its Ministry of Labour. According to a former official of this ministry, in 2014 the government deliberately changed the management of SUNAFIL in order to enhance its grip on the agency. An expert in labour law states that the labour inspectors previously based at the Ministry of Labour 'only changed the shirt' and in practice 'nothing has changed except the logo'. As a result of the continuing efforts by the government to control SUNAFIL, four different directors have been appointed since its creation in 2014.

Third, independence from companies is limited. One interviewee complained that in some cases labour inspectors are dependent on companies for their daily work, giving the example of an inspector who needed to rely on car transport provided by the company due to the lack of any transport of his own. Lack of fuel and transport, having to pay for transportation and being denied access to businesses are general problems for inspectors in Peru (US Department of Labor, 2014, p. 4). According to one interviewee, some labour inspectors have been hired by the companies that they previously needed to inspect.

Fourth, SUNAFIL's sanctioning power is limited. A law was passed determining that henceforth a 'preventive approach' would be taken to promoting labour rights in Peru. Instead of sanctioning companies that do not comply with labour law, the idea is to work on corrective measures that would be more effective in the long run. If SUNAFIL finds an employer to be in violation of labour law, this employer has three years to prevent and correct the violations (US Department of State, 2014, p. 38). At the same time, the new law has weakened the criminal responsibilities of employers for accidents at the workplace. Criminal penalties are limited to 'those cases where employers have 'deliberately' violated safety and health laws and where labour authorities have previously notified employers who have chosen not to adopt measures in response to a repeated infraction' (US Department of State, 2015, p. 34; see also below on the new health and safety law).

Interestingly, the 'weakening' of labour inspections has been recognised by the European Commission in its GSP+ report (European Commission, 2016, p. 257). The report points to new economic measures by the government that have limited the capacity for action of labour inspection'. An ILO official also confirmed that 'while the goal of the creation of SUNAFIL was to have a better labour inspection, in practice it has become worse because of a lack of resources'.

\subsubsection{De Facto Continuation of Special (Labour)} Regimes

Second, the continuation of the Agricultural Sector Promotion Law (Law No. 27360) and the blocking of the project for a unified labour law might be seen as going against the commitments in the chapter on trade and sustainable development. The special export regime for agriculture has existed since 2000 and was renewed in 2006 until the end of 2021. As stated before, the primary objective of the law was to support investment and development of the agricultural sector. The labour movement criticises the law for the flexibility that it provides to employers in the agricultural sector compared to the general labour law (e.g. halving holiday entitlements, longer 
working hours and lower compensation for unfair dismissal) (CEPAL et al., 2012b, p. 289).

Several sources also indicate that the law is no longer necessary, since its original objective was reached in the first ten years of its functioning (International Commission of Jurists, 2014, p. 9). Indeed, the purpose of the agricultural export law was to provide opportunities to Peruvian producers to integrate in the international economy. According to the International Commission of Jurists (2014), the law provides 'highly flexible contract systems that favour investment but at the same time promote precarious employment and discourage the formation of trade unions'. It further states that the law reduces the level of workers' protection with the aim of encouraging investment and promoting the growth of agro-exports. Precisely for this reason, a labour lawyer also posited that the law is unfair: it provides fewer benefits for the same work, solely to lower the labour cost for companies.

Over the past 15 years, the Peruvian labour law has become so fragmented that 'the exception has become the rule'. The general labour law has been hollowed out and, according to one interviewee, applies to only about $10 \%$ of employees. In 2013 , about $7 \%$ of all formally employed workers in Peru were working under the agricultural export law (Mujica, 2015, p. 6). There have been several attempts to streamline the agricultural export law, alongside other exceptional regimes, into one General Labour Law. Soon after the reinstatement of the 'Consejo Nacional de Trabajo y Promocion de Empleo' (or General Council of Labour and Promotion of Employment) (CNTPE, hereafter: National Council) in 2001, attempts were made to agree on a unified labour law (Ministerio de Trabajo Peru, n.d.). In 2011, new attempts were undertaken. While in 2012 there was allegedly a consensus on about $90 \%$ of the articles, there is no political will from the government, and there is also opposition to the project from the employers' side (Fernandez-Maldonado Mujica, 2015, p. 153; PLADES, 2014, p. 14). While the employers' side aimed to continue the discussion in the National Council, the labour groups wanted the Peruvian government to resolve outstanding issues.

It remains to be seen whether the agricultural export law will be extended again after 2021, something which two interviewees mentioned as a likely scenario. Meanwhile, the Peruvian Association of Exporters has requested the prolongation of Law No. 27360 until 2041, something for which President Kuczynski (in office since 2016) has already expressed support (Perú 21, 2016). Nonetheless, labour reform does not seem to be one of this President's priorities (Inside US Trade, 2016).

\subsubsection{De Jure Lowering of Health and Safety at Work}

The revision of the law on safety and health at work constitutes a clear example of a de jure weakening of labour law in Peru. Notably, this has happened since the entry into force of the trade agreement. In 2011, a law on safety and health at work was approved (Law No. 29783). It was considered to be a progressive law that had been elaborated with input from the labour movement. However, the new law was considered to bring along too many implementation costs for companies, which lobbied for its modification. As a result, it was amended in July 2014 (Law No. 30222), shortly after it entered into force (in April 2014). It was changed on several points, such as the frequency with which medical checks need to take place, and the need for redeployment within the same company following an industrial accident. Importantly, as mentioned above, the criminal responsibility of employers in the case of accidents at the workplace was lowered, making it less likely that accidents will lead to sanctions. Instead, the new law opts for a 'preventive approach'. This is an important aspect because in the construction sector alone there is at least one casualty per month. In addition, the modification of the law was passed without its submission to tripartite dialogue (PLADES, 2014, p. 14).

Although it seems clear that these modifications have weakened the level of labour protection, evaluations of the nature of these changes vary from being 'rather small' (according to a labour lawyer) to being '(very) significant' (according to NGOs and the labour movement). Trade unionists in the agricultural export sector state that the new law is not known or at least not applied by employers.

Similar to the creation of SUNAFIL, the original law on safety and health was one of the electoral promises made by President Humala (2011-2016). Again, however, his centre-left government proved unable or unwilling to implement the initiative. In the same context, it should be noted that more progressive members of the Ministry were dismissed and that a new Minister of Labour, who was considered to be closer to the business community, was installed. Because the economic and the political elite in Peru are closely interwoven, it becomes difficult even for centre-left politicians to create and enforce regulations and institutions that improve labour rights. This is further reinforced by the antiunion climate in Peru and the general Atlanticist, free trade orientation that has characterised the country in recent years.

These three sub-cases show that there are deficiencies in the law and practice of labour rights in Peru. However, it is more difficult to assess whether this violates the commitments in the trade agreement (see Table 1). In the cases of labour inspection and safety and health, there has been a de facto and de jure lowering of protection; however, it is difficult to ascertain whether this has (intentionally) encouraged trade or investment (with the $\mathrm{EU})$. In the case of the special agricultural sector promotion law, it is clear that a flexible labour regime has been established in order to stimulate export competitiveness; however, this system predates the entry into force of the trade agreement with the EU. In general, it is very difficult to prove that changes in labour rights protection 
Table 1. Summary of compliance with domestic labour law commitments

\begin{tabular}{lll}
\hline & Lowering since $\mathbf{2 0 1 3}$ & Encourage trade/investment \\
\hline Labour inspection & Yes (de facto) & $?$ \\
Special regimes & No (to be checked after 2021) & Yes \\
Health and safety & Yes (de jure) & $?$ \\
\hline
\end{tabular}

were put in place in order to encourage trade or investment. As such, the potential of the non-lowering clause in EU trade agreements seems rather compromised.

\subsection{Promoting Civil Society Dialogue}

The trade agreement provides that each Party 'shall consult domestic labour and environment or sustainable development committees or groups, or create such committees or groups when they do not exist' (Art. 281). The Peruvian government has opted not to create a new group but instead to consult existing committees. In the area of labour rights, this is the National Council. This decision does not go against the letter of the agreement, which also provides that the constitution and consultation of such committees or groups...shall be in accordance with domestic law' (Art. 281). However, in practice three issues emerge.

First, there is a consensus among our interviews with (former) members of the National Council that the domestic mechanism does not effectively exist (RedGe, n.d.). One civil society actor said that it is an ineffective space where 'you should send issues you don't want to succeed'. This was confirmed by an ILO representative who called the National Council ineffective, irregular and more consultative than deliberative'. The National Council seems to have become paralysed in the last two or three years. Several interviewees indicated that they did not know whether it had been convening again regularly or not.

Trade unionist (former) members complain that the government consistently ignores recommendations made by the National Council. In addition, they state that laws are being passed without consultation with the National Council, which did not even discuss the trade agreement with the EU. Some members, including some trade unions, have withdrawn from the Council in protest at this state of affairs. Some trade unionists argue that it only exists to give Peru an international image of social dialogue and is only there for photo opportunities. In addition, the National Council is not an independent mechanism. It is chaired by the Ministry of Labour, its convocation depends on the will of the Minister of Labour, and the presence of government officials in the meetings further jeopardises its autonomous functioning. This was confirmed by several interviewees. The European Economic and Social Committee (EESC) laments the presence of government representatives as going against the nature of such mechanisms as civil society bodies (EESC, 2016). This is not contrary to the letter of the agree- ment, however. Contrary to the EU agreement with Central America (Art. 294(4-5)), for example, the provisions on the domestic civil society mechanism do not specify that the members need to be 'independent'.

Second, from our interviews there are no indications that the implementation of the chapter on trade and sustainable development is discussed in this forum. In fact, the members of the Council whom we interviewed were not aware that, since the entry into force of the trade agreement with the $\mathrm{EU}$, they were tasked with the monitoring of this chapter. A representative of a major union in the agricultural sector was surprised to hear that the Council was also supposed to play such a role. Several EU DAG members confirmed that their Peruvian partners were not aware of a domestic mechanism. The EESC recently also lamented the fact that the Peruvian mechanism has never met to discuss the sustainable development aspects of the trade agreement with the EU (EESC, 2016). Interviewees in Peru are sometimes aware of the transnational meetings, but they do not know that there should also be a domestic component.

Taking all this into account, it is not surprising that the National Council has ostensibly not submitted any 'opinions' or 'recommendations' on the implementation of the chapter on trade and sustainable development, a possibility that is provided for in the agreement (Art. 281). The only coordinated initiative from civil society about the implementation of this chapter concerns a letter written by RedGe (Red Peruana por una Globalización con Equidad) and signed by 13 civil society organisations, addressed to the Head of the EU Delegation in Lima (RedGe, 2015). This letter expresses concerns about the deterioration of labour and environmental rights and criticises various changes to the law and policy. In addition, the authors request the EU to put these issues on the agenda of the intergovernmental Sub-Committee on Trade and Sustainable Development.

The non-functioning of the Peruvian DAG has been lamented by its EU counterpart. The EU DAG sent a letter to the Peruvian government asking for more information about the composition of the Peruvian (and Colombian) DAG so that the European DAG could contact its counterparts to coordinate (Iuliano, 2015). There has not been an official reply to this letter, but the Peruvian government has made it clear that issues related to social dialogue are a purely internal Peruvian matter. This was also made clear to us by the Peruvian Ministry of Trade. The EU Delegation in Lima also confirmed that, when requested for more information about the domestic civil society mechanism, such as the frequency of its meet- 
ings, the participating members, the agenda etc., the Peruvian government replied 'this is not your business'. While the treaty does not require the Peruvian government to provide this information, our interviews indicate that consultation has not taken place, which goes against the letter of Art. 281.

Third, the commitment to allow domestic stakeholders the opportunity to participate in the transnational sessions is also not being implemented (Art 282.2). Peruvian civil society has been underrepresented in the transnational civil society meetings. Thus far, three transnational civil society meetings have taken place in the context of the annual meeting of the Sub-Committee on Trade and Sustainable Development. The first meeting (Lima, in 2014) is generally seen as substandard or even 'terrible' as it was more a debriefing about the trade agreement than a true dialogue; what's more, as the meeting of the Sub-Committee was delayed by more than three hours, there was no time for the governments to really listen to civil society. In addition, the translation system did not work properly. The representative of one of the main union federations indicated that he had only been informed about the meeting two or three days earlier, which of course hampered effective preparation. Although the second meeting (Bogotá, in 2015) was evaluated as more substantial by some observers, no members of Peruvian civil society were present. Their absence was due to various factors, including their lack of capacity, limited budgets, and other priorities; yet it seems clear that the Peruvian government had not facilitated their involvement in any way. Several of our interviewees from Peruvian civil society as well as some members of the EU DAG confirmed that there had been no announcements by the authorities in Peru in relation to the transnational meeting. The third meeting (Brussels, in 2016) was described by the organisers as an historic achievement because civil society representatives from all three countries were present. This claim should, however, be put into perspective. Peruvian civil society participation was very limited and no Colombian civil society participated; a Dutch organisation represented Colombian interests instead. In addition, video conferencing was meant to overcome the distance and related funding issues. However, the link did not work until half way through the meeting. The dysfunctionality of the Peruvian National Council and presence of officials during its meetings were repeatedly criticised; however, the Peruvian officials made it clear that there were no prospects of a new ad hoc mechanism (in contrast to Colombia). In conclusion, the research shows that the Peruvian government failed to empower a domestic mechanism that can perform the monitoring role effectively, to consult this group, and to facilitate its participation in the transnational meetings. This should be seen in the context of a general unwillingness to include civil society actors in the discussions on the implementation of the trade agreement.

In sum, it seems that the restrictive legal provisions on civil society meetings, which grants considerable lee- way to the Peruvian government (see Section 3), have an impact on the de facto involvement of civil society. While it has yet to be determined whether the meetings function more effectively in practice under EU trade agreements with more far-reaching provisions on civil society involvement, ongoing research on the EU-Korea and EU-Central America agreements suggests that this is the case. At least, Korean and Central American DAG members are aware of their role in the trade agreements, linkages with the transnational meetings are more established, and the independence of members is less contested. European Commission officials whom we interviewed also admitted that it was a mistake not to specify that DAG members need to be independent, adding that this had been remedied in subsequent agreements.

\section{Conclusions}

This article has shown that the EU's legal improvement, institution building and empowerment impact in promoting labour rights through its trade agreement with Peru has been non-existent. First, the legal provisions were drafted in a conservative way that leaves ample flexibility for the Peruvian government, even compared to other EU agreements. Second, these provisions have not been fully implemented and have even been violated in a number of cases. We identified serious shortcomings with the implementation of ILO core conventions, the lowering of domestic labour law, including labour inspection, and the near-absence of civil society dialogues. While it may be too early to draw definite conclusions, as ongoing large-N studies suggest that promotional labour clauses may reduce breaches of labour rights in the long run, this detailed sector and interview-based case study of Peru's compliance with core labour rights, health and safety regulations, labour inspection, export promotion regimes and civil society mechanisms illustrates the complexity of EU trading partners' compliance with labour rights commitments. In addition to its empirical contribution, the article has, we hope, set the stage for further comparative analysis with other sectors and countries by making use of the proposed analytical framework.

In terms of explanations for the non-impact of the trade agreement, we can point to the role of the Peruvian government, interests of the agro-export sector, and the traditional anti-union climate. In addition, it is clear that the EU has not strongly insisted on more robust provisions in the chapter on trade and sustainable development and that it has been relatively responsive to the Peruvian and Columbian governments' reservations in this regard. The EU's reluctance to take firm action against violations of trading partners' (core) labour rights already characterised the GSP+ trading regime with Peru that preceded the trade agreement (even if theoretically the former system was more enforceable through trade sanctions). Officials interviewed at the Commission's DG Trade concede that some language in the chapter on trade and sustainable development should have been 
stronger and suggest that they have taken these lessons into account for subsequent agreements. To what extent this has indeed been the case and what this means for the practical application of labour rights remains to be studied in further research.

Although there are inherent limits to what trade agreements can achieve in terms of promoting labour rights, the EU could clearly have pushed more in both the negotiation and the implementation of the trade agreement (see Orbie \& Van den Putte, 2016). For instance, during the trade negotiations the EU could have insisted on specific reforms in areas such as labour inspection (pre-ratification conditionality), and could have demanded the inclusion of a social safeguard clause (when liberalisation has unforeseen negative consequences) as well as sanctions as a last resort. During the implementation, it could insist more on getting information about the existence and functioning of the DAG within Peru (within the intergovernmental Sub-Committee on Trade and Sustainable Development), it could enhance the effective functioning of the civil society meetings (through budgetary and administrative support), it could foster coherence with its own development cooperation policy in Peru (which also involves civil society dialogue, albeit independently from the trade agreement), and engage in cooperation with other actors such as the US (which has filed a complaint against labour rights violations in Peru) and the ILO (which has the relevant expertise but is not formally involved). Given the rising politicisation of trade policy, the debates on the sustainable development dimension of free trade agreements are undoubtedly going to continue and the European Commission has recently published some interesting ideas in a nonpaper on this topic (Barbu et al., 2017; European Commission, 2017).

When observers and academics characterise the EU's approach as being 'soft', they usually refer to the absence of sanctions (Campling et al., 2016; Horn et al., 2010; International Institute for Labour Studies, 2013, 2016; Vogt, 2014). However, this analysis shows that even when we leave the sanctions debate aside, the EU is being soft in the sense that it does not seriously implement its promotional approach. Even without changing the existing treaty provisions, the EU could push much harder to realise its soft approach.

\section{Acknowledgments}

First and foremost, we gratefully acknowledge financial support from 11.11.11., Coalition of the Flemish NorthSouth Movement, which commissioned this study. Furthermore, we would like to thank the numerous Peruvian and European interviewees who provided extremely valuable information and insights. Thank you to the anonymous reviewers for their helpful and constructive comments, which contributed greatly to improving the final version of the paper. We also owe a debt of gratitude to Werner Raza from the Austrian Foundation for
Development Research for enabling the publication of an earlier version of this work in the ÖFSE Working Paper Series.

\section{Conflict of Interests}

The authors declare no conflict of interests.

\section{References}

Barbu, M., Campling, L., Ebert, F., Harrison, J., Martens, D., Marx, A., ... Smith, A. (2017, September 26). A response to the non-paper of the European Commission on Trade and Sustainable Development (TSD) chapters in EU Free Trade Agreements (FTAs). Retrieved from http://www.geog.qmul.ac.uk/media/geography /docs/research/working-beyond-the-border/A-Re sponse-to-the-Nonpaper-26.09.17.pdf

Barrientos, S., \& Smith, S. (2007). Do workers benefit from ethical trade? Assessing codes of labour practice in global production systems. Third World Quarterly, 28(4), 713-729.

Brown, R. C. (2015). Asian and US perspectives on labor rights under international trade agreements compared. In A. Marx, J. Wouters, G. Rayp, \& L. Beke (Eds.), Global governance of labour rights: Assessing the effectiveness of transnational public and private policy initiatives (pp. 83-117). Cheltenham: Edward Elgar.

Campling, L., Harrison, J., Richardson, B., \& Smith, A. (2016). Can labour provisions work beyond the border? Evaluating the effects of EU free trade agreements. International Labour Review, 155(3), 357-382.

CEPAL, OIT, \& FAO. (2012a). Empleo y condiciones de trabajo de mujeres temporeras agrícolas. Retrieved from http://www.fao.org/3/a-as122s.pdf

CEPAL, OIT, \& FAO. (2012b). Políticas de mercado de trabajo y pobreza rural en América Latina. Retrieved from http://www.fao.org/3/a-i2644s.pdf

Cheong, D., Jansen, M., \& Peters, R. (2013). Shared harvests: Agriculture, trade, and employment. Geneva: International Labour Office.

Ebert, F. C., \& Posthuma, A. (2011). Labour provisions in trade arrangements: Current trends and perspectives. Geneva: International Institute for Labour Studies.

EESC. (2016). Briefing of the EESC secretariat on the functioning of Domestic Advisory mechanisms in EU Trade Agreements. On file with the author.

European Commission. (2016). The EU special incentive arrangement for sustainable development and good governance ('GSP+') covering the period 2014-2015 (SWD(2016) 8 final). Brussels: European Commission.

European Commission. (2017). Trade and sustainable development (TSD) chapters in EU Free Trade Agreements (FTAs). Brussels: European Commission. Retrieved from http://trade.ec.europa.eu/doclib/ docs/2017/july/tradoc_155686.pdf 
Ferm, N. (2008). Non-traditional export industries: Conditions for women workers in Colombia and Peru. Gender and Development, 16(1), 13-26.

Fernandez-Maldonado Mujica, E. (2015). Peru: De la Ley General del Trabajo al Regimen Laboral 'Pulpin'. Apuntes para una aproximación al proceso laboral (2000-2014). CENDES, 32(89), 141-171.

Fonds voor Ontwikkelingssamenwerking. (2015). Trabajadores de la agroindustria: Registro de casos para el tribunal ético del Perú.

FORLAC. (2014). Trends in informal employment in Peru: 2004-2012. Notes on Formalization. Retrieved from http://www.ilo.org/wcmsp5/groups/public/--americas/---ro-lima/documents/publication/wcms_2 45891.pdf

Gansemans, A., Martens, D., D'Haese, M., \& Orbie, J. (2017). Do labour rights matter for export? A qualitative comparative analysis of pineapple trade to the EU. Politics and Governance, 5(4), 93-105.

Gil Piedra, R., \& Grompone Velásquez, A. (2014). Sindicalismo y política en el Perú: Una breve aproximación en perspectiva comparada. Serie de Documentos de Trabajo, 2.

Horn, H., Mavroidis, P. C., \& Sapir, A. (2010). Beyond the WTO? An anatomy of EU and US preferential trade agreements. The World Economy, 33(11), 1565-1588.

Inside US Trade. (2016, July 27). Questions linger on incoming Peruvian president's stance on labor law reforms. Inside US Trade. Retrieved from https:// insidetrade.com/daily-news/questions-linger-incom ing-peruvian-presidents-stance-labor-law-reforms

International Commission of Jurists. (2014). Social rights and special regimes for export promotion: The case of the agriculture for export in Peru. Retrieved from http://icj.wpengine.netdna-cdn.com/wp-content/up loads/2014/11/Peru-Social-Rights-for-Export-Promo tion-Publications-thematic-report-2014-ENG.pdf

International Institute for Labour Studies. (2013). The social dimensions of free trade agreements. Geneva: Institute for Labour Studies.

International Institute for Labour Studies. (2016). Assessment of labour provisions in trade and investment arrangements. Geneva: Institute for Labour Studies.

International Labor Rights Forum. (2015). Public submission to the Office of Trade and Labor Affairs (OTLA) under chapters 17 (labor) and 21 (dispute settlement) of the Trade Promotion Agreement between the United States and Peru. Retrieved from https:// www.dol.gov/ilab/media/pdf/PTPA\%20submission_ July\%2023\%202015_English\%20translation.pdf

International Labour Organization. (n.d.). Trade union density rate Peru. International Labour Organization. Retrieved from http://www.ilo.org/ilostat/faces/ oracle/webcenter/portalapp/pagehierarchy/Page27. jspx?subject=IR\&indicator=ILR_TUMT_NOC_RT\&data setCode=A\&collectionCode=IR\&_afrLoop $=42409186$ 863134\&_afrWindowMode=0\&_afrWindowld=19iga
qq5xk_46\#!\%40\%40\%3Findicator\%3DILR_TUMT_NO C_RT\%26_afrWindowld\%3D19igaqq5xk_46\%26subje ct\%3DIR\%26_afrLoop\%3D42409186863134\%26data setCode\%3DA\%26collectionCode\%3DIR\%26_afrWind owMode\%3D0\%26_adf.ctrl-state\%3D19igaqq5xk_78

International Trade Union Confederation. (2017). ITUC global rights index: The world's worst countries for workers. Retrieved from https://www.ituc-csi.org/ IMG/pdf/survey_ra_2017_eng-1.pdf

International Trade Union Confederation. (n.d.). Survey of violations of trade union rights. International Trade Union Confederation. Retrieved from http:// survey.ituc-csi.org/Peru.html\#tabs-3

Iuliano, G. (2015). Letter of the president of the EU DAG for the EU-Peru-Colombia trade agreement to the copresidents of the Subcommittee on Trade and Sustainable Development.

Lieberwitz, R. L. (2006). Linking trade and labor standards: Prioritizing the right of association. Cornell International Law Journal, 39(3), 641-653.

Martens, D., Van den Putte, L., Oehri, M., \& Orbie, J. (in press). Mapping variation of civil society involvement in EU trade agreements: The CSI index. European Foreign Affairs Review, 23(1).

Marx, A., Wouters, J., Rayp, G., \& Beke, L. (Eds.). (2015). Global governance of labour rights. Assessing the effectiveness of transnational public and private policy initiatives. Cheltenham: Edward Elgar.

Ministerio de Trabajo Peru. (n.d.). Ley General de Trabajo. Ministerio de Trabajo y Promoción del Empleo. Retrieved from http://www.mintra.gob.pe/portal inclusivo/mostrarContenido.php id $=656 \&$ tip $=655$

Mujica, J. (2015). Incumplimiento de las obligaciones contraídas en materia laboral en el Acuerdo de Cooperación Comercial celebrado entre la Unión Europea y Colombia y Perú (Annex of the letter by RedGe to the EU ambassador in Peru).

Oehri, M. (2015a). Comparing US and EU labour governance 'near and far'-Hierarchy vs network? Journal of European Public Policy, 22(5), 731-749.

Oehri, M. (2015b). US and EU labor governance in the Dominican Republic: Contrasting the DR-CAFTA and the CARIFORUM-EPA de jure and de facto. Bulletin for Comparative Labour Relations, 89, 93-112.

Orbie, J., \& Tortell, L. (2009). New GSP+ beneficiaries: Tickling the box or truly consistent with ILO findings? European Foreign Affairs Review, 14(5), 663-681.

Orbie, J., \& Van den Putte, L. (2016). Labour rights in Peru and the EU trade agreement: Compliance with the commitments under the sustainable development chapter (Working Paper No. 58). Vienna: Austrian Foundation for Development Research (ÖFSE).

Orbie, J., \& Van Roozendaal, G. (2017). Labour standards and trade: In search for impact and alternative instruments. Politics and Governance, 5(4), 1-5.

Organisation for Economic Co-operation and Development. (2015). Multi-dimensional review of Peru: Volume I. Initial assessment. Paris: OECD Publishing. 
Perú 21. (2016). ADEX pide reformas para el sector agroexportador. Peru 21. Retrieved from http:// peru21.pe/economia/adex-pide-reformas-sector-agro exportador-2242634

PLADES. (2014). La agenda laboral pendiente del TLC Perú-Estados Unidos: Cuando la competitividad se base en la reducción de los derechos laborales. Retrieved from https://www.iesiperu.org.pe/documen tos/publicaciones/TLC\%20EEUU\%20PERU.pdf

Postnikov, E., \& Bastiaens, I. (2014). Does dialogue work? The effectiveness of labor standards in EU preferential trade agreements. Journal of European Public Policy, 21(6), 923-940.

RedGe. (n.d.). TLC con la UE no garantiza proteccion de derechos laborales TLC Peru/Colombia-UE: Analisis de temas sensibles.

RedGe. (2012). Derechos laborales y empleo en la agroexportación. RedGe. Retrieved from http://www. redge.org.pe/node/1427

RedGe. (2015). Carta a la Senora Embajadora Irene Horejs de la Unión Europea en el Peru.

Schuster, M., \& Maertens, M. (2017). Worker empowerment through private standards. Evidence from the Peruvian horticultural export sector. The Journal of Development Studies, 53(4), 618-637.

Sulmont Samain, D. (2006). La concertacion sociolaboral en el Peru. Gouvernance Globale du Travail. Retrieved from http://www.ggt.uqam.ca/spip.php? article851\&lang=fr

UNICEF. (n.d.). UNICEF data: Monitoring the situation of children and women: Peru. UNICEF. Retrieved from http://data.unicef.org/countries/PER

United Nations Development Programme. (2015). Human development report Peru. Retrieved from http:// hdr.undp.org/sites/all/themes/hdr_theme/countrynotes/PER.pdf

United States Department of Labor. (2014). Peru 2014 findings on the worst forms of child labor. Retrieved from http://www.dol.gov/ilab/reports/childlabor/findings/2014TDA/peru.pdf

United States Department of Labor. (2016). Public report of review of U.S. submission 2015-01 (Peru). Retrieved from https://www.dol.gov/ilab/reports/ pdf/Public_Report_of_Review_of_US_Submission_ 2015-01.pdf

United States Department of State. (2014). Peru 2014 human rights report. Retrieved from http://www. state.gov/documents/organization/236922.pdf

United States Department of State. (2015). Peru 2015 human rights report. Retrieved from http:// www.state.gov/documents/organization/253247.pdf Van den Putte, L., \& Orbie, J. (2015). EU bilateral trade agreements and the surprising rise of labour provisions. International Journal of Comparative Labour Law and Industrial Relations, 31(3), 263-283.

Van Roozendaal, G. (2017). Where symbolism prospers: An analysis of the effects on enabling rights of soft and hard labour standards provisions in trade agreements with South Korea. Politics and Governance, 5(4), 19-29.

Velazco, J., \& Pinilla, V. (2017). Development models, agricultural policies, and agricultural growth: Peru, 1950-2010 (DT-SEHA n. 1704). Retrieved from http:// repositori.uji.es/xmlui/bitstream/handle/10234/168 364/DT-SEHA\%201704.pdf?sequence=1\&isAllowed =y

Velluti, S. (2015). The EU's social dimension and its external trade relations. In A. Marx, J. Wouters, G. Rayp, \& L. Beke (Eds.), Global governance of labour rights: Assessing the effectiveness of transnational public and private policy initiatives (pp. 42-62). Cheltenham: Edward Elgar.

Verbeek, B. (2014). Globalisation and exploitation in Peru: Strategic selectivities and the defeat of labour in the US-Peru trade promotion agreement. Global Labour Journal, 5(2), 212-232.

Verité. (n.d.). Risk analysis of indicators of forced labor and human trafficking in illegal gold mining in Peru. Retrieved from https://www.verite.org/wp-content/ uploads/2016/11/Indicators-of-Forced-Labor-in-Gold -Mining-in-Peru_0.pdf

Vogt, J. (2014). Trade and investment arrangements and labor rights. In L. J. Blecher, N. Kaymar Stafford, \& G. Bellamy (Eds.), Corporate responsibility for human rights impacts: New expectations and paradigms (pp. 121-176). Chicago, IL: American Bar Association.

Vogt, J. (2015). A little less conversation: The EU and the (non) application of labour conditionality in the generalized system of preferences (GSP). International Journal of Comparative Labour Law and Industrial Relations, 31(3), 285-304.

Vogt, J. (2017). The Bangladesh Sustainability Compact: An effective tool for promoting workers' rights? Politics and Governance, 5(4), 80-92.

Walk Free Foundation. (2014). The global slavery index 2014. Walk Free Foundation. Retrieved from http://www.globalslaveryindex.org

World Bank. (2017a). Employment in agriculture (\% of total employment) in Peru. World Bank. Retrieved from https://data.worldbank.org/indicator/SL.AGR.EMPL. ZS?end $=2014$ \& locations $=$ PE\&start $=1990$

World Bank. (2017b). Value added (\% of GDP) of agriculture in Peru. World Bank. Retrieved from https:// data.worldbank.org/indicator/NV.AGR.TOTL.ZS?loca tions $=P E$ 


\section{About the Authors}
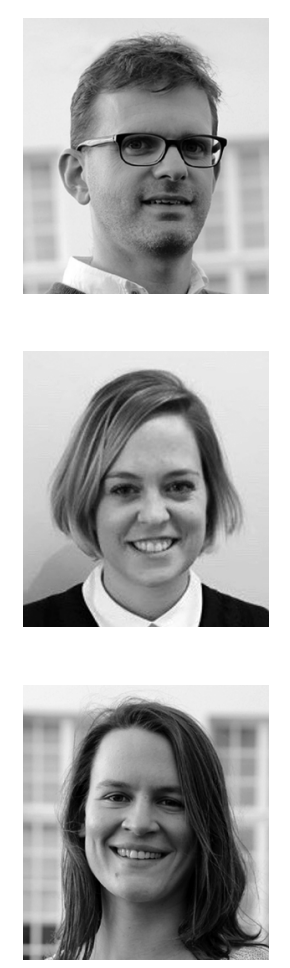

Jan Orbie is the director of the Centre for EU Studies (CEUS) and a professor at the Department of Political Science at Ghent University. His primary research focus is on the EU's foreign policy and specifically the 'soft' (trade, development, social, democracy promotion) dimensions of EU external relations. In particular, he follows closely the interaction between the trade, development and foreign policies from an EU perspective. He teaches on similar subjects within Ghent University's Master EU Studies programme.

Lore Van den Putte obtained her PhD in September 2016 at the CEUS and is now an associated researcher at the Centre. Her research concerns the promotion of labour norms in EU (as well as US) bilateral trade agreements. In particular, she focuses on the role of civil society mechanisms, the European Parliament and the trade agreements with Peru-Colombia and Korea. This research involves extensive fieldwork in Colombia, Peru, the US and Canada. She currently works as research and training officer at the Institute for Research and Education on Negotiation (IRENE) at ESSEC Business School. In this capacity she delivers trainings in negotiations to EU officials.

Deborah Martens is a PhD candidate at the CEUS since December 2014. She works on an interdisciplinary research project with Annelien Gansemans, from Ghent University's department of agricultural economics, on the impact of the EU trade on social development in Latin America. Together, they aim at understanding how labour conditions in the agricultural sector are influenced by trading with the EU. Concretely, they combine the macro-level (EU politics), meso-level (Corporate Social Responsibility of EU firms) and micro-level (pineapple plantations in Central America) in their research. 